\title{
Eksamen er kultur
}

Anmeldelse af Rie Troelsen, Leder af SDU Universitetspoedagogik, Syddansk Universitet.

Eksamen og eksamensformer - betydning og bedømmelse

Hanne Leth Andersen, RUC og Jens Tofteskov, CBS

Samfundslitteratur, 2016 (2. udgave)

194 sider

Bogen Eksamen og eksamensformer - betydning og bedømmelse udkom første gang i 2008. Nu har forfatterne Hanne Leth Andersen, som er professor i Universitetspædagogik og rektor for RUC, og Jens Tofteskov, som er chefkonsulent på CBS Teaching and Learning, opdateret førsteudgaven - helt generelt og i særdeleshed med et kapitel om det særegent danske eksamenssystem. I sin væsentlighed er denne bog således ikke forskellig fra førsteudgaven, men regler og forordninger med reference til eksamen er blevet opdateret, kapitler er blevet flyttet rundt, og alt i alt giver det en bedre læseoplevelse.

Bogen er opdelt i tre dele, som på sin vis repræsenterer en kronologi: hvilke overvejelser bør man gøre sig inden eksamen (del 1); hvordan udføres den konkrete eksamensform (del 2) og hvordan vurderes eksaminanden efter endt eksamination (del 3).

I bogens første del finder vi kapitler om overordnede kriterier for valget af eksamensform, det være sig sammenhæng mellem læringsmål, læringsaktiviteter og eksamen, eksamens rolle i opnåelsen af uddannelsens generelle kompetencemål, formulering af læringsmål som afsæt for en tydelig eksamination, overvejelser om validitet, reliabilitet og andre distinkte karakteristika i relation til den enkelte eksamensform. Jeg vil især fremhæve kapitlet om eksamenssystemets institutionelle funktion(er), fordi det giver stof til eftertanke omkring eksamensformens relation til progressionen i uddannelsen. For at tilfredsstille krav om fleksibilitet, valgfrihed og STÅindtægter vælger nogle uddannelser at splitte undervisningsforløb op i mindre og mindre enheder. Og da vi gerne vil give de studerende så meget og så hyppig feedback som muligt på, hvor langt de er kommet i deres læringsrejse, så kan mange små stop være en god idé. Risikoen er imidlertid, at ingen tager ansvar for sammenhængen og progressionen op gennem uddannelsen. Samtidig er eksamen i mange tilfælde - i hvert fald hos de studerende - en mere tydelig retningsgiver end de i studieordningen formulerede læringsmål, og derfor spiller eksamensformerne en væsentlig rolle i bestræbelserne på at skabe sammenhæng. Forfatterne beskriver forskellige måder at tænke progression på: fører den ene disciplins kompetencer til den næstes, og skal eksamensformen derfor blive mere og mere kompleks - eller peger hver disciplins læringsmål på en del af uddannelsens generelle mål, og skal eksa- 
mensformen derfor være ens/lige kompleks? Heldigvis er der i dette kapitel ingen svar, for svarene ligger hos hver studienævn/undervisergruppe/uddannelsesleder det er blot at gå i gang med at diskutere!

Bogens anden del gennemgår en lang, men ikke udtømmende, række af eksamensformer; fra mundtlige eksamener over portfolioeksamener til kandidatafhandlinger. Hver eksamensform beskrives ud fra dens egne præmisser. I kapitlet om mundtlig eksamen behandles således forskellige spørgsmålstyper (åbne-lukkede, konkreteabstrakte), eksaminationens faser samt rollefordelingen mellem eksaminator og censor, hvorimod kapitlet om kandidatafhandlinger går ind i spørgsmål om den studerendes arbejde med afhandlingen og vejlederens rolle heri, indtil vedkommende skifter til eksaminatorrollen. I alle kapitler skinner en dyb forståelse og indsigt i styrker og svagheder ved den enkelte eksamensform dog igennem. Hvad enten man står som ny underviser og skal forestå en eksamen for første gang eller er en erfaren underviser, der vil ændre sit kursus' gængse eksamensform, er bogen derfor generøs i sine muligheder for at blive klogere på den enkelte eksamensform.

Den tredje del af bogen er rettet mod bedømmelse, karaktergivning, censur og plagiat. Her behandles bedømmelseskriterier (processuelle, absolutte eller relative), karakterskalaens fokus med styrker og/eller mangler, censorinstitutionens fordele og ulemper samt årsager til plagiat. Herefter følger et kapitel om typiske udfordringer for udenlandske undervisere ved det danske eksamenssystem. Det er som sådan ikke et kapitel til udenlandske undervisere (dertil ville sproget nok være den første barriere), men et kapitel om de særlige forhold ved det danske eksamenssystem, som personer, der er opvokset med det, ikke længere er bevidste om. Det være sig censorinstitutionen, den mundtlige eksamen og studienævnenes styring og kontrol af det enkelte kursus' eksamensform. I dette kapitel bliver det fremhævet, at eksamen er kultur. Det er den i høj grad, og derfor er det vigtigt, at eksaminatorer, uddannelsesplanlæggere, studieledere og censorer gør sig umage med at eksplicitere den tavse viden, der sammen med regler og forordninger er forbundet med eksamen - ikke kun for udenlandske undervisere, men også for sig selv, hinanden og ikke mindst de studerende. Og det gælder ikke kun om emner som censur, mundtlig eksamen og studienævnets rolle - det gælder faktisk for alle eksamensformer, deres begrundelser, udførelser og vurderinger. Jævnlig refleksion over, hvorfor vi netop eksaminerer, som vi gør, kunne føre til mangen nødvendig tydeliggørelse/forbedring/ændring/afskaffelse...

I sin helhed behandler bogen eksamen i teori og praksis, dvs. hvad eksamen ideelt set burde leve op til, og hvordan den i praksis gennemføres. Det gør den på en forskningsbaseret måde, som gør den til en solid og praksisforankret grundbog for alle, der enten vil udvikle på eksamensformen eller blot ønsker indsigt i styrker og svagheder ved den gældende eksamensform - fra kursusniveau til uddannelsesniveau. 